\title{
Is the private rented sector desirable in Slovenia? Examining the role of the state in the development of the sector
}

The private rented sector (PRS) in Slovenia has operated since the end of the Second World War without being officially recognised and supported by government policy. This article explores why the responsible state institutions have persistently ignored this sector. The discussion starts with a brief review of the development of the country's housing policy, which has been deeply entrenched in the "enabling approach" philosophy since the major housing reforms were introduced in the early 1990s. With the help of the findings of a survey conducted among the key state institutions responsible for housing care, the role of the state is examined in the development of the private rented sector since a market economy system was adopted in Slovenia in 1991. Although the responses received from the survey show that the state institutions investigated are generally aware of all the shortcomings of the current PRS, they have made no serious attempt to support its development. A suggestion is therefore made in the conclusion that the failure to introduce the measures necessary to support the development and formal operation of the PRS may be attributed to unfavourable attitudes of policymakers toward the sector.

Keywords: private rented sector, tenure structure, housing policy, enabling principle, state institutions, Slovenia 


\section{Introduction}

As an important segment of housing provision, the private rented sector (PRS) has been and continues to be the subject of constant discussion within the housing research community worldwide. There is an abundance of sources with various authors addressing various aspects of the PRS (e.g., Boelhouwer \& van der Heijden, 1992; Malpass \& Means, 1993; Forrest \& Murie, 1995; McCrone \& Stephens, 1995; Balchin, 1996; Boelhouwer \& van der Heijden, 1996; Crook \& Kemp, 1996). Recognising its various positive attributes, the common viewpoint has been that a properly organised PRS is urgent because it plays an important role in maintaining an adequate supply of dwellings as well as contributing an alternative option to homeownership. These views notwithstanding, it has also been generally observed in the literature that the sector has suffered a steady decline over the last decades, which in some countries has made it comparatively less important. There is consensus among some authors that the residualisation of the PRS was due to shifts in housing policies that increasingly favoured and promoted homeownership as a more desirable form of tenure as opposed to renting (see, e.g., Harloe, 1985; Ruonavaara, 1990; Forrest \& Murie, 1991; Dieleman \& Everaers, 1994; Rossi \& Weber, 1996; Elsinga \& Hoekstra, 2005; Stamso, 2008; De Decker \& Dewilde, 2010; Doling \& Ronald, 2010; Kleinhans \& Elsinga, 2010; Toussaint, 2011). Despite the observed phase of general decline, the PRS has nonetheless always played an important role in western European countries and is expected to continue to do so (Gray \& McAnulty, 2008; Hulse \& Pawson, 2010; Kemp, 2011; Crook \& Kemp, 2014). In the case of the UK, for example, it has been reported that the sector has recently grown in size after a period of decline (Kemp, 2015). It has also been noted that the PRS is increasingly being utilised by lower income groups that previously would have been housed in the social housing sector, which has gradually shrunk and become less accessible to various categories of low-income households (Scanlon \& Kochan, 2011).

On the other hand, a thorough examination of literature on the subject in post-communist central and eastern European (CEE) countries shows that this important segment of housing tenure has only been scantly addressed in academic discourse. The details concerning its nature and manner of functioning have barely been investigated. The characteristic lack of attention to the subject may, for example, be evidenced in one of the earliest publications discussing the anticipated market orientation of the housing sector in eastern Europe at the time of the shift from a planned economy to a market economy (Telgarsky \& Struyk, 1990). Although the publica- tion included a section on "Housing allocation and tenure" for each country covered by the study, private rented housing was barely mentioned. Other authors (such as Turner et al., 1992; Struyk, 1996; Mandič, 2000; Priemus \& Mandič, 2000; and Donner, 2006) only briefly mentioned the PRS in their various contributions on housing in CEE countries. The discussion on Hungary presented only a general overview of the sector, admitting that "As a matter of fact, there are no statistical data on the size of the private rental housing sector" (Erdosi et al., 2000: 272). For Croatia, Sasha Tsenkova (2009: 127) wrote "It is considered that the sector [PRS] is larger, but functions to a large extent as part of the informal economy." On the topic in the Czech Republic, Martin Lux and Petr Sunega (2010) address the development of the PRS only from the perspective of the state policies that were implemented after introducing housing reforms. In the follow-up to this publication, Lux and Martina Mikeszova (2012) examine the way the restitution of previously nationalised property impacted the PRS and the entire Czech housing system. Property restitution constitutes the focus of the discussion for both articles.

Because the subject has so far been inadequately researched in the CEE region, there is as yet no empirically founded and convincing explanation for why post-communist countries generally continue to ignore the PRS. In his works on the subject, Peter Kemp $(1987,2015)$ has argued that private rental (like all other housing tenures) is a form of institution with relatively settled characteristics for periods of time. He has suggested that it is this enduring nature of housing tenures that helps the market function. "It enables buildings to be bought and sold, and to be let by landlords to tenants, under more or less well-defined defined terms and conditions" (Kemp, 2015: 603). In other words, the PRS cannot function properly if the basic terms and conditions essential for its operation are not well defined and established. This assertion presents the principle hypothesis for the discussion in this article.

The article thus sets out to examine the role of the state in the operation of the PRS in Slovenia. First I present a brief historical review of Slovenia's housing policy developments, identifying the adoption of the "enabling principle" (introduced by the 1991 housing reforms) as the key policy milestone. This is followed by a presentation on the current situation of the PRS and the impact of implementing the enabling approach on its development. Against this background, I present and discuss the findings of a survey that I conducted among the key state institutions responsible for housing issues. In the conclusion, I propose some explanations for why the state has consistently failed to implement the necessary measures to create the basic conditions for formal and efficient operation of the PRS. 


\section{Housing policy development}

To better understand the issues discussed here, it is necessary to first present a brief historical review of the developments of the last two decades or so that have (or ought to have) impacted the development of the PRS. Slovenia adopted a market economy system in 1991, a change that was simultaneously accompanied by (among other things) implementing drastic housing reforms. The key housing reform measures introduced by the 1991 Housing Act included abolishing state financing for new housing construction, privatising the public housing stock and the restitution of previously nationalised housing to its rightful owners. The most visible immediate effect of these reforms was, of course, a sharp increase in the level of homeownership (from 67\% before privatisation to $89 \%$ after privatisation) and the consequent significant reduction in the size of the rental stock. Soon after this, there began to appear a housing supply shortage (especially new dwellings) as a direct consequence of abolishing state financing for new construction. Together, these events resulted in a steady increase in housing prices throughout the 1990s until 2008, when the global financial crisis began and halted the price increases.

The devolution of the responsibility of the state to provide housing was implemented on the basis of a new housing policy mantra, which was popularly known at the time as the "enabling principle". The enabling principle had previously been adopted and globally recommended by the General Assembly of the United Nations as an appropriate strategy for improving shelter problems (United Nations Centre for Human Settlements, 1988). As the term itself implies, adopting the "enabling principle" essentially meant shifting the role of the state from that of a provider to that of an enabler. Concretely, instead of providing housing, the state would henceforth create conditions to enable citizens to resolve their housing needs on their own. The enabling approach was readily embraced worldwide and its implementation intensified across Europe throughout the 1990s and beyond. The impact of this policy change on housing situations in various countries has been extensively discussed (Forrest \& Murie, 1990; Kemp, 1991; Cole \& Furbey, 1994; Malpass, 1997; Pearl, 1997; Karn \& Nyström, 1998; Ridley, 1988; Monk \& Whitehead, 2000; Boulhouwer, 2002; de Decker, 2002; Kristensen, 2002; Matznetter, 2002; Pareja Eastaway \& Varo, 2002; Priemus \& Dieleman, 2002; Turner \& Whitehead, 2002; Gruis et al., 2009).

Upon its adoption in Slovenia, the National Housing Policy (NHP) document defined the "enabling principle" as a modern approach adopted to replace the outdated doctrine of housing provision. It was written that the principle aim was to "achieve the de-bureaucratisation of the housing sector and the replacement of administrative housing allocation by the measures necessary for setting up a housing market and offering support to private initiative" (National Housing Programme, Sln. Nacionalni stanovanjski program, Ur. l. RS, no. 43/2000: 5771). ${ }^{[1]}$ From now onwards, the state would provide assistance through various forms of benefits only to those groups of the population that were not capable, financially or otherwise, of resolving their housing needs by themselves; that is, the lowest income groups and specific vulnerable categories of the population.

Among the numerous goals set by the NHP, the following specially relate to the development of the PRS:

- Establishing partnerships between the public and private sectors;

- Providing a legal and organisational framework for the coordinated operation of all involved in housing;

- Ensuring equilibrium of housing supply and demand in order to maintain a sufficient number of dwellings for purchase and rental purposes in cases of inadequate supply or high demand and

- Encouraging and promoting the operation of the housing market and its positive effects on social and economic development.

In the brief explanation of these goals, it was recognised that, due to the constant high demand for rental housing, especially in large cities and regional centres, there was a need for some consumers to resolve their housing needs within the private rented sector. These needs, it was stated, would be satisfied only on the condition that market conditions were established to guarantee potential landlords a suitable yield on their investment. The document also specified the need to provide some minimum level of protection for private rental contracts which, while securing tenant tenure, would not discourage landlords from offering their property on the rental market. The end goal was to gradually extend private investments (at the time almost exclusively orientated towards achieving homeownership) to investments in housing for rental purposes as well.

According to the NHP, the new role of the state would be twofold:

1. To apply appropriate measures to influence money markets for providing housing construction loans. Such intervention on the real estate market would encourage competitiveness and bring about market improvements, which would lead to an increase in supply and a reduction in demand. By offering tax incentives, particularly with respect to real estate taxation, the government would be able to gradually achieve more economic use of the existing stock. 
2. The government and local authorities would especially encourage the construction, renewal and purchase of nonprofit and social rental housing. Incentives would also be provided to mobilise personal savings for investment in the private rented sector, in addition to encouraging investment in homeownership.

Implementing the enabling approach measures described above ought to have resulted in establishing alternative tenure choices (Mandič \& Filipovič Hrast, 2015) and led to the creation of a suitable foundation for the formal operation and gradual development of the PRS. However, a detailed analysis conducted in 2007 (seventeen years after introducing housing reforms) on the achievements of implementing the NHP concluded that almost none of the NHP goals had been realised (Sendi, 2007). The presentation in the following section provides proof that the goals relating to the PRS were certainly not achieved.

\section{The current PRS in Slovenia}

Although implementing housing reforms seriously impacted the level of supply and housing prices generally, it is difficult to accurately evaluate the impact of this policy change on the PRS. The reason for this is that, when housing reforms were introduced, there was no PRS in Slovenia (according to official statistical records). Throughout its post-war history, statistical data on housing tenure never included figures for private rented housing. Until 1994, data were presented only for the public-sector and private-sector tenures. In 1995, these categories were changed to legal person and natural person, respectively. This manner of presenting tenure data was even more problematic. Whereas "natural person" may be understood to mean private/individual ownership, the term "legal person" effectively includes both the public sector and private sector large/institutional investors, who normally have the status of a legal entity. Thus, in addition to an absence of data on private rented stock, official statistical data did not provide information on the share of public housing separately from that of private institutional investors. My view on this issue is that this ambiguous format of presenting data may have been deliberately adopted in order to conceal the true share (very minimal) of public-sector tenure.

Notwithstanding the non-publication of data on this housing tenure, it has always been widely acknowledged that the PRS exists. The service was provided even before the adoption of the market economy, was quietly tolerated by the communist regime and was left to cater to those that were not able to satisfy their housing needs otherwise (Sendi, 1995, 1999). Surprisingly, the non-publication of data on the size of the sector continued even after introducing the market economy system and
Table 1: Tenure structure within occupied dwelling stock.

\begin{tabular}{lll}
\hline Tenure & Number of dwellings & Share (\%) \\
\hline Owner-occupied & 523,070 & 78.06 \\
\hline Rent-free & 84,905 & 12.67 \\
\hline Rented & 62,152 & 9.27 \\
\hline Not-for-profit & 43,438 & 6.48 \\
\hline Market & 12,378 & 1.85 \\
\hline Employer & 4,405 & 0.66 \\
\hline $\begin{array}{l}\text { Institutional (elderly, } \\
\text { students etc.) }\end{array}$ & 1,931 & 0.29 \\
\hline Total occupied stock* & 670,127 & 100 \\
\hline
\end{tabular}

Note: ${ }^{*}$ Total occupied stock $=$ Owner-occupied + Rent-free + Rented Source: SURS (2013).

housing reforms, which were expected, among other things, to also encourage the development of the PRS. On publishing the results of the national census in 2012, the Statistical Office of the Republic of Slovenia (SURS) reported the following: a total of 844,656 dwellings, of which 761,300 (90\%) were owned by natural persons, $47,348(6 \%)$ owned by the public sector, 27,798 (3\%) owned by other legal entities and 8,210 (1\%) categorised as employer housing (SURS, 2012). Although a distinction was made this time between the public sector and other legal entities, the initial report did not include any information on the size of the PRS.

However, a major milestone occurred in this area with the release of a more detailed report that was published a year later, in 2013. SURS finally paid heed to the longstanding requests by researchers for published data on the private rented stock. Officially referred to as market housing (Table 1), this was the first time that such data were published since SURS was created in 1944.

According to the data presented in Table 1, the share of private rented housing accounted for $1.9 \%$ of the total occupied housing stock. Although nobody in the country knows exactly what the true size of the PRS is, there is a general consensus among housing experts that this figure is not accurate. Having been persistently ignored by official state policy, the sector mainly operates illegally; that is, without formal registration. The figure stated in Table 1 represents only the private rentals that, at the time of the census, had been registered with the responsible local authorities. I argue that the share of the PRS is much higher than that specified in the table. There are two additional pieces of data published in the 2011 census upon which I base my challenge to the validity of the official figure on the PRS tenure. First, the census determined that $21 \%$ of the total stock was unoccupied; that is, vacant. Second, 13\% of the occupied stock was categorised as dwellings used as rent-free tenure. SURS defines the latter as dwellings that are occupied by persons that are not owners but do not pay any 
rent (such as relatives, friends and the like). In both cases, there is a high likelihood that a certain proportion of the "vacant" and "rent-free" dwellings are actually let out on the private rented market. The issue here is that the method used by SURS to gather census data does not make it possible to verify the true use or nature of tenure of the dwellings. Moreover, although free-rent tenure is also known in some other countries (see, e.g., Scanlon \& Kochan, 2011 for the United States and Crook \& Kemp, 2014 for Spain), what is striking in the case of Slovenia is that rent-free tenure accounts for $58 \%$ of the total non-owner-occupied stock. Although there still is no reliable source of accurate information on the true nature of the so-called "vacant" and "rent-free" categories of tenure in Slovenia, all housing experts generally agree that a certain share of this stock is let out on the grey market. As Hugo Priemus and Srna Mandic (2000) once noted, the current Slovenian PRS is known for being an extension of the owner-occupied sector.

\section{Examining the role of the state}

The investigation of why the state institutions responsible for housing have persistently neglected the PRS was centred around examining their views regarding the existence and importance of the sector. This investigation focused on answering the following key questions:

1. Do the key state institutions recognise the importance and potential role of the PRS?

2.. What (if any) specific reservations or objections do they have to the existence and successful operation of the PRS?

3. What is their opinion regarding the current situation whereby the PRS continues to be ignored by the state?

4. What (in case in favour of its existence) do they suggest as urgent measures for the successful development and operation of the PRS?

\subsection{Method}

Because the investigations were directed at specified state institutions, I naturally adopted the deliberate sampling methodology. First, I drew up a list of the public institutions that I wanted to investigate. I then designed several self-administered questionnaires with the relevant questions for each individual institution. Given the nature of the survey, these were structured questionnaires with open-ended questions intended to explore, as much as possible, the attitudes, viewpoints and activities of the institutions investigated.

The questionnaires were initially sent by post, but an electronic version was also available upon the request of the participat- ing institutions. The survey covered the following major stakeholder public institutions:

1. Key ministries:

- The Ministry of Infrastructure and Spatial Planning (directly responsible for housing) and

- The Ministry of Finance.

2. All political parties represented in the National Assembly at that time, together with the responsible parliamentary expert committee (the National Assembly Committee for Infrastructure and Spatial Planning). ${ }^{[2]}$

3. The Housing Fund of the Republic of Slovenia (a parastatal body responsible for implementing national housing policy).

Completed questionnaires were returned by all the institutions covered by the survey, apart from three of the parliamentary parties. The questions varied with respect to the particular institution surveyed, but three questions constituted the core of the investigation. In addition to these, one question was specially sent only to the parliamentary political parties.

The survey questions were:

1. Question one

According to the census data published in 2012:

- $90 \%(761,300)$ of housing units were owned by private individuals

- $6 \%(47,348)$ of them were in public-sector ownership

- $3 \%(27,798)$ were owned by another legal entity

- $1 \%(8,210)$ were categorised as "owner unknown".

a) What is your comment on these data? What is your viewpoint regarding the share of housing units owned by private individuals (90\%)? Is this share appropriate, too high or too low?

b) What is your viewpoint on such a manner of presenting statistical data, which does not include information on the number (or share) of housing units rented on the private market? ? $^{[3]}$

\section{Question two}

According to the census data published in 2012, there were "up to $175,000(20.7 \%)$ vacant dwellings"

a) What is your viewpoint on the information that one-fifth of the entire housing stock is vacant?

b) Is it necessary to adopt any kind of tax measures in connection with this?

c) If so, which measures in particular?

\section{Question three}

a) Is the (name of institution) of the opinion that a PRS is necessary? If so, why?

b) If you believe that a PRS is necessary, are you also in favour of ensuring its effective operation through specific government 
financial support? If so, what form of financial support do you suggest (e.g., subsidies, tax breaks etc.)?

c) What is the viewpoint of (name of institution) regarding the current supply of private rental housing and the current manner of operation of the PRS?

\section{Question four (sent only to parliamentary parties)}

Has the (name of parliamentary party) ever discussed or considered the situation of the PRS and its manner of operation in Slovenia?

a) If so, regarding what specifically? Have any problems been noticed in this area? If so, which ones and what were the conclusions of the parliamentary group discussion?

b) Do you have any specific suggestions for measures to regulate the activity or operation of the private housing rental sector? Please state specific measures applying to:

1. Legal arrangements (tenants' rights, owners' rights etc.)

2. Taxation

3. Financing

4. Rental policy

5. Other:

\section{Survey results and discussion}

The discussion about the responses of the institutions surveyed focuses on the following key aspects of the investigation:

- Current tenure structure and manner of data presentation;

- Vacant dwellings and measures for dealing with the problem;

- Current supply and manner of operation of the PRS;

- Need for an efficient PRS and

- Role of the national legislative body.

The first general observation to be made about the results of the survey is that the institutions investigated did not always fully respond to the questions asked. Furthermore, I also found that some of the responses were either vague, irrelevant or evasive.

\subsection{Current tenure structure and manner of data presentation}

The National Assembly Committee for Infrastructure and Spatial Planning recognised that the share of housing owned by private individuals was too high. However, the committee was ambiguous in its response. On the one hand, it appeared to express doubts regarding the capability of households to cover the costs of renting, subtly implying that there may not be much need for private rented housing. On the other hand, it was conscious of the financial hardships encountered by homeowners burdened with mortgage obligations. In the end, the committee remained unclear about its final position regarding the current tenure structure.

That the homeownership tenure is too large is a view also held by the Ministry of Infrastructure and Spatial Planning. Responding to a question specifically asked of this ministry regarding the accuracy of tenure data, it boldly claimed that it had a "rough estimate" of the share of the size of the private rented stock. Then it went on to quote the exact figure published by the Statistical Office of the Republic of Slovenia; that is, 12,387 dwellings (as presented in Table 1). This response provides proof that the ministry directly responsible for formulating housing policy within the government has neither accurate information on nor a rough estimate of the true size of the PRS. A lack of such knowledge on the part of this particular ministry inevitably entails its incapacity to formulate appropriate policies in this area.

The view that the share of homeownership tenure is too high was also expressed by Parliamentary Party 2 as well as by the Ministry of Finance. Commenting on the tenure structure, the Housing Fund of the Republic of Slovenia suggested that the current situation was a consequence of the previous (communist) political system and its housing policies. It continued to explain that the majority of Slovenians aspire to own their home, that short-term rental is often only a temporary solution and that long-term rental on the private market is rare in Slovenia. I certainly agree with the observation regarding the general Slovenian obsession with becoming homeowners. However, I do not fully accept the argument that the current tenure structures are necessarily the consequence of the previous communist system. Given that homeownership accounted for $67 \%$ of the total stock at the end of the communist regime in 1991, its growth to $90 \%$ by the 2011 census indicates that the government policies that were implemented after introducing a market economy system must have also favoured its further development and growth. Privatising the previous public housing stock and the various housing subsidisation schemes (all measures implemented after adopting a market economy) did considerably contribute to the growth of homeownership tenure. Citizens may, indeed, aspire to achieve a variety of personal goals, but the state always has the capacity to regulate and control developments, especially those that impact the national economy and general wellbeing of the population. My underlying argument here is that the state failed (or deliberately chose not) to guarantee the conditions that would make it possible to develop alternative tenures, such as private rental. 
The response of Parliamentary Party 4 to the same question about tenure structure was more accurate and in agreement with my own view because it distinctly placed the blame for the current tenure structure on the government policies that were implemented after Slovenia became independent. Similarly, Parliamentary Party 3 made reference to the role of state housing policy, stressing the impact that demand-side-oriented policies had had on house price increases, resulting in a difficult-to-access housing market for young housing-seekers. Parliamentary Party 4 also identified a major problem of the current PRS in that, on the one hand, it was operated by an unregulated real estate market and, on the other hand, it was governed by inappropriate taxation policies.

Like the Ministry of Finance, Parliamentary Party 3 also pointed out the inappropriateness of the data-gathering method at the national level and the failure to perform efficient market controls. On this issue, Parliamentary Party 1 acknowledged that the current methodology for gathering data and the manner of presenting it do not reflect the true tenure situation in the country.

Summing up, all of the institutions investigated recognise, in one way or another, that the share of homeownership is too high and that that of the rental stock is too low. Similarly, all of the respondents are aware of the inadequacies of the manner of gathering and presenting data on housing tenure. They all also appreciate the need to gather and present housing tenure structures in a manner that would also make it possible to identify and publish data on the PRS.

\subsection{Vacant dwellings and measures to deal with the problem}

The National Assembly Committee for Infrastructure and Spatial Planning responded to the question about vacant dwellings with only one single statement: "Our view is that vacant housing should be taxed." Such a response may be understood as an indication of the "not-very-concerned" attitude of one of the key state institutions regarding this important housing market defect. The Ministry of Finance provided a more detailed response to the question. Its basic view was that dwelling vacancy is of secondary importance from the perspective of property taxation because this does not influence the tax base. However, it recognised the need to achieve economical use of the existing housing stock and, to this end, proposed introducing specific taxation measures. These two views may be understood to suggest that the Ministry of Finance sees taxation in this area as an instrument for combating dwelling vacancy and not as a mechanism for raising revenue for the state budget. On the one hand, this may be a commendable position, but on the other hand it could be construed as one explanation for government inaction in this area, given that the ministry responsible for fiscal policy does not envisage any economic benefit for the state budget from taxing vacant dwellings.

Acknowledging that the share of vacant dwellings is too high, Parliamentary Party 1 suggested that the problem needed to be urgently addressed by introducing suitable incentives intended to fill the vacant housing stock. Along similar lines, Parliamentary Party 2's position was that there was a need to adopt more favourable tax policies that would bring vacant dwellings onto the rental market as soon as possible. In contrast to the suggestion by the Ministry of Finance, Parliamentary Party 2 questions the appropriateness of potentially taxing vacant dwellings. Alternatively, it proposes a tax break for privatesector landlords (for a specified initial period), with the aim of removing one of the arguably most important reasons (a high tax rate) for performing the activity illegally. The same view was shared by Parliamentary Party 4, which suggested that private-sector investors should be motivated to put their vacant properties on the rental market through lowering taxes on rental income. Similarly, Parliamentary Party 3 was also inclined towards a more supportive tax policy for the PRS. It further stated that the majority of landlords would be interested in offering longer-term rental contracts (it provided no supporting evidence for this expectation) if the regulations allowed for terminating contracts, should any justifiable need arise. Other than the tax measures, both Parliamentary Party 1 and Parliamentary Party 2 also proposed introducing measures aimed at intensifying control over the operation of the PRS.

The responses presented in this section show that all of the institutions investigated find the existence of such a large number of vacant dwellings inappropriate. There are two main policy proposals to this effect. The National Assembly Committee for Infrastructure and Spatial Planning and the Ministry of Finance see the solution in taxing vacant properties. On the other hand, the parliamentary parties generally favour introducing favourable tax policies, which would act as an incentive for private investors.

\subsection{Current supply and manner of operation of the PRS}

The response of the National Assembly Committee for Infrastructure and Spatial Planning to this question was simply "We are not familiar with the situation." If this was a sincere response - and there is no reason to understand it otherwise - it reveals quite a lot about the seriousness of the body of the legislature primarily responsible for discussing and proposing housing policy measures to the parliament. This response clearly demonstrates the committee's attitude towards the PRS and may help explain why the situation of the PRS is as it is today. 
The Ministry of Infrastructure and Spatial Planning, on the other hand, saw the current PRS as "problematic due to the large number of dwellings allegedly rented out illegally". By using the word allegedly, the ministry directly responsible for housing effectively admitted (once again) that it had no accurate knowledge about the actual scope of the rental activity on the private market. It did, however, mention the duration of judicial processes dealing with rental disputes as one of the major problems of the current PRS. These procedures last three years on average but may take up to five or more years to conclude.

In its response to this question, Parliamentary Party 1 raised the issue of the non-transparency of the operation of the PRS, which, in its view, leads to abuse and the grey economy. Regarding the inadequacies of the current supply of privately rented housing, Parliamentary Party 2 explained in its response that this was, among other reasons, due to landlords' unwillingness to risk letting their property to tenants that may not regularly pay the rent. Like the Ministry of Infrastructure and Spatial Planning, it also saw lengthy court proceedings in the case of a dispute as a major obstacle to the efficient operation of the PRS. This may indeed be true. In addition to the high level of taxation, I also share the view that lengthy court procedures may act as a major disincentive to potential investors in the sector.

There are three major observations to be made regarding the responses in this section. First, the institutions investigated have no accurate knowledge about the scope of activity on the private rented market. However, they are all aware that there is an active PRS, which operates illegally. Most of them also recognise that the lengthy judicial procedures for resolving landlord-tenant disputes constitute a major deterring factor to the successful operation of the PRS.

\subsection{Need for an efficient PRS}

Here, it is vital to recall the precise question that the respondents were asked: "Is the (name of institution) of the opinion that a PRS is necessary? If so, why?" I consider this to be one of the two core questions of the survey. With it, I wanted to determine (or at least obtain an idea of) whether or not the institutions investigated consider the PRS a necessary segment of the housing market. This question was thus intended to help more concretely explore why the PRS has been constantly ignored by policymakers.

The National Assembly Committee for Infrastructure and Spatial Planning was, once again, very brief: "The PRS would probably be necessary in a certain share proportionate to that of the non-profit sector." This response is problematic in two ways. First, the word probably indicates that the central parliamentary body responsible for housing policy is not sure whether the PRS is necessary at all. Second, it is inappropriate, at this point in time, to suggest that the size of the PRS should be determined as a certain proportion of the non-profit sector. The current size of the non-profit sector (as shown in Table 1) cannot be a meaningful basis upon which to determine the appropriate share of the PRS. This, once again, is a response that indicates that the major legislative body is not seriously concerned about the existence and proper functioning of the PRS.

Responding to this question, the Ministry of Finance was even more indifferent. Its answer was simply "Such issues do not fall within the responsibilities of the Ministry of Finance." In view of the more detailed explanations given by the same ministry in response to some of the other questions asked, there may be two ways of interpreting this statement: either the ministry does not know whether the PRS is necessary, or it simply does not care.

The response of the Ministry of Infrastructure and Spatial Planning to this question was also very brief, although more straightforward. Its opinion was that an efficient and transparent PRS is necessary in order to guarantee greater access to housing, and it also saw the sector as a segment of the housing system with the potential to facilitate higher population mobility. In comparison with the responses given by the Parliamentary Committee and the Ministry of Finance, this is, indeed, a more positive and constructive viewpoint. However, this response also makes it even harder to understand why the ministry directly responsible for formulating housing policy and proposing the relevant laws and regulations has so far failed to act to achieve these objectives.

Like the Ministry of Infrastructure and Spatial Planning, the majority of the parliamentary parties were all affirmative and clear in their responses. Parliamentary Party 1 recognised that the PRS was necessary as a complementary housing supply segment to public-sector housing. Parliamentary Party 2 was more emphatic because it envisaged the PRS as the backbone of the rental housing market, in which private rented housing "should constitute a normal component of private capital investment, both domestic and foreign". Parliamentary Party 4 expressed an opinion similar to that of Parliamentary Party 2, affirming that the PRS is necessary and must be a constitutive part of the housing market in Slovenia. In addition, it also took the position that government intervention in the housing market should be kept to the minimum possible level. Although this standpoint sounds perfectly legitimate at first, my view is that it also needs to be recognised that from time to time the housing market requires various forms of government intervention 
in order to counter various market distortions that may create situations of unacceptable disequilibrium in the levels of housing supply and demand. At this point, I strongly argue that the current situation in Slovenia calls for serious government intervention in the PRS before deregulation can be effected and the housing market left to operate on its own.

Although the response of Parliamentary Party 3 to this question was indirect, its suggestion to conduct a preliminary thorough analysis of the market situation may be understood as a positive and supportive stance towards the existence of the PRS. It also proposed that there needs to be appropriate coordination between the relevant ministries in order for the PRS to function efficiently.

With the exception of the Ministry of Finance (which opted for a non-responsible stance), all of the institutions surveyed seem to agree that the PRS is necessary. This is one of the most important findings of this survey. It is clear that the major state institutions are, in principle, not against the existence of the sector. It is clear that there is a general consensus among policymakers that an efficient PRS is necessary. However, notwithstanding this new information, the fact remains that the sector has consistently been ignored by these very institutions that have the constitutional and legal powers to enable it to function normally. Thus, the key question that still needs to be answered is why this is so. The responses given below to the question that was asked only of parliamentary parties may provide some indication of where the core problem lies.

\subsection{Role of the national legislative body}

I stated above that the question regarding the need for the PRS was one of the two core questions of the survey. The second core question is the one I only asked the parliamentary parties: "Has the (name of parliamentary party) ever discussed or considered the situation of the PRS and its manner of operation in Slovenia?" This question was intended to explore which concrete activities had been performed in this area by the elected representatives of the citizens, who have the constitutional powers to formulate and adopt the appropriate housing legislation and policies.

In response to the question, the National Assembly Committee for Infrastructure and Spatial Planning admitted that, during the duration of its term (the third year running at the time the survey was conducted), the committee had not held a single discussion on the topic. Parliamentary Party 1 explained that it had discussed the operation of the PRS only in connection with the discussion on general social and family issues. Parliamentary Party 2 stated that it was planning to discuss the issue as part of the discussion on the new National Hous- ing Program that was under preparation at the time. Neither Parliamentary Party 3 nor Parliamentary Party 4 gave a direct response to the question. Instead, each of them provided a list of suggestions of the measures it would like to see included in the new national housing programme, which, as already stated, was being prepared by the Ministry of Infrastructure and Spatial Planning. Failing to provide a relevant answer to the question leads to the conclusion that neither of the two parliamentary parties had discussed the subject.

As may be clearly understood from the responses to this question, not a single parliamentary party ever specifically and concretely discussed the issue of the operation of the PRS. Although all of the parliamentary parties that participated in the survey appeared to be relatively knowledgeable about the situation of the PRS, and especially its shortcomings, none of them had felt the need to discuss the issue and propose (or at least try to propose) adopting appropriate legislation and suitable policy measures to the parliament. This may, indeed, be the most important finding of the survey in the search for why the sector has been ignored and left in limbo all along.

\subsection{Summary of the responses}

Through their responses, all of the state institutions investigated showed that they are well aware of the inadequacies of the current PRS. All of them admit that the present tenure structure is inappropriate, given such a high level of homeownership at the cost of the rented sector. They also admit that they have no accurate information on the share of the private rented tenure. There is also a common consensus that the manner of publishing tenure data does not reflect the true situation on the market. It is also commonly agreed that the number of vacant dwellings, as reported by the census results, is too high. However, the measures suggested by the various institutions for dealing with this problem are generally diametrically opposed. On the one hand, some advocate taxing vacant dwellings, whereas, on the other hand, implementing more favourable fiscal measures (as suggested by the majority) is seen as an incentive that would encourage landlords to put their properties on the market. My view is that the latter would be a more efficient approach to solving the problem. The respondents are also aware of Slovenia's lengthy judicial procedures, which are believed to deter some potential landlords from entering the private rented market. However, most importantly, all (except the Ministry of Finance, which failed to state its opinion on the issue) agree that the PRS is necessary. This revelation helps remove all doubts that may have existed in the minds of all of those that have been constantly frustrated by the passive role of the state in this area. Furthermore, it is important to note that the institutions examined have also suggested numerous measures (the majority of them appropriate) 
that need to be taken to create a suitable foundation for the operation of the PRS.

Generally, the findings of the survey are quite encouraging, which is a great relief, at least for the research community. However, this then makes it even more incomprehensible why the PRS continues to be ignored. Given the indicated favourable stance of the state institutions towards the sector, it is difficult to understand why these institutions (each one with its own responsibilities on housing issues) have not yet acted to enable the normal operation of the PRS. It is still unclear why - after adopting the "enabling principle" as the mode that would lead to the promotion, development and normal operation of the PRS - the state totally failed to implement any of the measures that were specified and intended to enable the sector to formally function as a legitimate segment of the housing market. In the search for an explanation, it is suggested in the conclusion that the failure of the state to acknowledge the importance of the PRS and provide the legislative and institutional framework required for its normal functioning may be attributed to specific unfavourable attitudes harboured by, and within, the major policymaking institutions.

\section{Conclusions}

The first part of this article discussed the fact that the promotion and development of the PRS in Slovenia had been ambitiously proclaimed by the new national housing policy that was adopted after introducing housing reforms and implementing the enabling approach. Through the new policy, the government would create conditions that would encourage private investment in the PRS and guarantee potential landlords a suitable return on their capital investment. However, as shown above, the state failed to successfully implement the enabling principle and, as a consequence, the Slovenian PRS continues to largely operate informally, with all of the inevitable corresponding negative attributes of a grey market activity. Before proceeding to suggest some explanations for the lack of state support for the development of the sector, it is necessary to briefly examine what, precisely, the essence of the principle of "enabling" was.

Although the enabling principle was widely adopted as one of the major welfare state retrenchment policies across Europe, some scholars raised doubts about the capacity of the principle for successful implementation in practice. For example, Martyn Pearl (1997: 53) cautioned "Although all local authorities are expected to become enablers, there is no single, binding definition of what such a role might entail." Ian Cole and Barry Goodchild (1995: 53) argued that "enabling" is an ambiguous catchword and found it to be ". . . a rather slippery concept when placed under closer scrutiny ... without consensus as to what form a model of enabling might take." Discussing the shift from provider to enabler within the broader context of housing governance, Robina Goodlad (1993) observed that the discussion about the process of transforming local authorities from landlord to enabler had often tended to be too simplistic. She cautioned about the numerous political complexities that often impact the relationship between the public and private sectors in implementing housing policies. As Lennart Lundquist (1991) also noted, housing provision is an activity that involves complex interrelations between various elements and actors at various stages. In his detailed study on the subject of housing provision, Peter Ambrose (1991) designed a very useful model with which he precisely defined the specific roles that must be played by both the public- and private-sector actors at each stage of what he called the "housing provision chain". Crucially, he described the role of the private-sector actors in the housing provision chain as follows: "Their level of activity, and their success, clearly depends on the legal and subsidy framework within which they are working - in other words on aspects of state housing policy" (1991: 95). This means that the private sector always operates in environments that are regulated and appropriately controlled through legislation and other relevant policies adopted by the state. More concretely, the state controls and executes the basic mechanisms that set into motion the initial stages of the entire provision process. The key role of the state is also stressed by Michael Oxley (2004: 8), who observes that "Housing and land markets do not exist in the absence of customs, laws and conventions that are determined by social and political processes. Markets do not exist independently of the state and governments." On the premise of this theoretical context, it can thus be argued that the situation of the PRS in Slovenia is the direct and logical consequence of the inertness of the state that failed to play its "enabling role" role within the housing provision chain.

On the other hand, however, I have determined that the key institutions that participated in the survey appear (albeit with varying views) to be generally in favour of a formal and normally operating PRS. So why, then, has this general consent not been translated into practical realisation? Given that the sector has not received any support from any of the various consecutive governments that have been in power since the introduction of housing reforms, I am inclined to suggest an explanation for the current state of affairs that puts the blame simply on unfavourable attitudes towards the sector on the part of the key state institutions. Among the various responses provided by the institutions investigated, it is possible to discern some views that reveal certain attitudes that I propose may have contributed to the prevailing situation. These are:

- Attitude 1: The National Assembly Committee for Infrastructure and Spatial Planning could not decisively state whether it would support adopting policies aimed 
at strengthening the PRS, as opposed to policies that have previously almost entirely favoured increasing the level of homeownership.

- Attitude 2: The responses from the Ministry of Finance generally indicate that the PRS and the entire discussion on the topic is irrelevant to it. Because it views the PRS as a segment that does not present a potential source of national budget revenue, it has shown, through its responses, that it is not much concerned whether the PRS exists or not. It should be pointed out that the role of this ministry in establishing a formal PRS is crucial because it would have to approve (within the government) all fiscal measures intended to create a suitable economic environment and provide the state support required for the successful functioning of the sector.

- Attitude 3: The National Assembly Committee for Infrastructure and Spatial Planning candidly admitted that it is not familiar with the current manner of operation of the PRS. In other words, this admission indicates that the body of the legislature directly responsible for housing matters has not taken the trouble to determine what is going on in the PRS.

- Attitude 4: The National Assembly Committee for Infrastructure and Spatial Planning indicated that the PRS "would probably be necessary" as a certain proportion of the not-for-profit sector. It is difficult to treat this as a serious suggestion in view of the fact that the not-for profit sector itself has been steadily dwindling in size and is continuing with this trend.

- Attitude 5: The responses to the question asked of parliamentary parties are, arguably, the most indicative. Notwithstanding the non-convincing attempts of the responding parliamentary parties to give an impression that they had worked on these issues, their answers clearly show that none of them had paid any meaningful attention to the PRS. After all, if they had, their actions would have resulted in some concrete and visible improvements.

Summing up, the failure of responsible state institutions to act to implement measures that would result in positive changes in the sector is an indication that they do not fully appreciate the positive role that the PRS can play as an alternative tenure to homeownership. I am thus suggesting that there may be other complex ideological factors that are impacting the views and attitudes of politicians towards the PRS. I actually admit that I still do not have definitive answers to these questions. Perhaps the policymakers simply do not want to create and support an efficient PRS. Perhaps the state is deliberately pursuing a policy that aims at achieving maximum homeownership. Perhaps the next research on the subject should focus on investigating the attitudes of policymakers towards homeownership instead of investigating attitudes towards the PRS.

Richard Sendi

Urban Planning Institute of the Republic of Slovenia, Ljubljana,

Slovenia

E-mail: richard.sendi@uirs.si

\section{Acknowledgement}

I am grateful to the Slovenian Research Agency, which funded a three-year research project, part of the findings of which have been presented and discussed in this article.

\section{Notes}

${ }^{[1]}$ The preparation of the new national housing policy was provided for in the 1991 Housing Act. However, the first Draft National Housing Policy was approved by the government in 1995 and submitted to parliament for debate and eventual adoption. For reasons unknown, the final National Housing Programme was adopted by the National Assembly only in 2000. In the interim period, the 1995 draft served as the official housing policy document (although it was not yet adopted by parliament).

${ }^{\text {[2] }}$ At the time of the investigation, there were seven political parties in the National Assembly. Given that some of these parties later changed their names or ceased to exist after failing to obtain sufficient votes during subsequent parliamentary elections, I refer to the political parties investigated in this discussion as Parliamentary Party 1, Parliamentary Party 2 and so on.

[3] The questionnaire was prepared and sent to the various state institutions investigated before the Statistical Office of the Republic of Slovenia released the 2013 publication, which at my request also included data on the private rented housing stock for the first time ever.

\section{References}

Ambrose, P. (1991) The housing provision chain as a comparative analytical framework. Scandinavian Housing and Planning Research, 8(2), pp. 91-104. DOI: 10.1080/02815739108730263

Ambrose, P. (1992) The performance of national housing systems: A three-nation comparison. Housing Studies, 7(3), pp. 163-176. DOI: $10.1080 / 02673039208720733$

Balchin, P. (ed.) (1996) Housing policy in Europe. London, Routledge.

Boelhouwer, P. (2002) Trends in Dutch housing policy and the shifting position of the social rented sector. Urban Studies 39(2), pp. 219-236. DOI: $10.1080 / 00420980120102939$

Boelhouwer, P. \& van der Heijden, H. (1992) Housing systems in Europe: Part 1. A comparative study of housing policy. Delft, Delft University Press.

Boelhouwer, P. \& van der Heijden, H. (1996) The private rental sector in Western Europe. Housing Studies, 11(1), pp. 13-33. DOI: $10.1080 / 02673039608720843$

Cole, I. \& Furbey, R. (1994) The eclipse of council housing. London, Routledge. 
Cole, I. \& Goodchild, B. (1995) Local housing strategies in England: An assessment of their changing role and content. Policy and Politics, 23(1), pp. 49-60. DOI: 10.1332/030557395782227348

Crook, A. D. H. \& Kemp, P. A. (1996) The revival of private rented housing in Britain. Housing Studies 11(1), pp. 51-68. DOI: $10.1080 / 02673039608720845$

Crook, T. \& Kemp, P. A. (eds.) (2014) Private rental housing. Comparative perspectives. Cheltenham, Edward Elgar.

De Decker, P. \& Dewilde, C. (2010) Home-ownership and asset-based welfare: The case of Belgium. Journal of Housing and the Built Environment, 25, pp. 243-262. DOI: 10.1007/s10901-010-9185-6

Dieleman, F. \& Everaers, P. C. J. (1994) From renting to owning: Life course and housing market circumstances. Housing Studies, 9(1), pp. 11-25. DOI: $10.1080 / 02673039408720772$

Dol, K. \& Haffner, M. (eds.) (2010) Housing statistics in the European Union 2010. Delft, OTB Research Institute for the Built Environment.

Doling, J. \& Ronald, R. (2010) Property-based welfare and European homeowners: How would housing perform as a pension? Journal of Housing and the Built Environment, 25, pp. 227-241.

DOI: 10.1007/s10901-010-9184-7

Donner, C. (2006) Housing policies in Central Eastern Europe. Vienna Christian Donner.

Elsinga, M. \& Hoekstra, J. (2005) Homeownership and housing satisfaction. Journal of Housing and the Built Environment, 20(4), pp. 401-424. DOI: 10.1007/s10901-005-9023-4

Erdösi, S., Hegedüs, J. \& Somogyi, E. (2000) Is private rental an option for urban housing provision in Hungary? Journal of Housing and the Built Environment, 15(3), pp. 267-291. DOI: 10.1023/A:1010137519113

Forrest, R. \& Murie, A. (eds.) (1991) Selling the welfare state. The privatisation of public housing. London, Routledge.

Forrest, R. \& Murie, A. (eds.) (1995) Housing and family wealth - comparative international perspectives. London, Routledge.

Goodlad, R. (1993) The housing authority as enabler. Coventry, Institute of Housing and Longman.

Gray, P. \& McAnulty, U. (2008) The increased role of the private rented sector in catering for low-income groups in Northern Ireland. European Journal of Housing Policy, 8(4), pp. 361-377. DOI: 10.1080/14616710802449588

Gruis, V., Tsenkova, S. \& Nieboer, N. (2009) Management of privatised housing. International policies and practice. Chichester, Wiley-Blackwell.

Harloe, M. (1985) Private rented housing in the United States and Europe. London, Croom Helm.

Hulse, K. \& Pawson, H. (2010) Worlds apart? Lower-income households and private renting in Australia and the UK. International Journal of Housing Policy, 10(4), pp. 399-419. DOI: 10.1080/14616718.2010.526403

Karn, V. \& L. Nyström (1998) The control and promotion of quality in new housing design. In: Kleinman, M., Matznetter, W. \& Stephens, M. (eds.) European integration and housing policy, pp. 125-154. London, Routledge.

Kemp, P. A. (1987) Some aspects of housing consumption in late nineteenth century England and Wales, Housing Studies, 2(2), pp. 1-16. DOI: $10.1080 / 02673038708720585$

Kemp, P. A. (2011) Low-income tenants in the private rental housing market. Housing Studies, 26(7-8), pp. 1019-1034.

DOI: 10.1080/02673037.2011.615155
Kemp, P. A. (2015) Private renting after the global financial crisis. Housing Studies, 30(4), pp. 601-620. DOI: 10.1080/02673037.2015.1027671

Kemp, P. A. \& Kofner, S. (2010) Contrasting varieties of private renting: England and Germany. International Journal of Housing Policy, 10(4), pp. 379-398. DOI: 10.1080/14616718.2010.526401

Kemp, R. L. (ed.) (1991) Privatization. The provision of public services by the private sector. London, McFarland \& Company.

Kleinhans, R. \& Elsinga, M. (2010) "Buy your home and feel in control": Does homeownership achieve the empowerment of former tenants of social housing? International Journal of Housing Policy, 10(1), pp. 41-61. DOI: 10.1080/14616710903573757

Kristensen, H. (2002) Social housing policy and the welfare state: A Danish perspective. Urban Studies 39(2), pp. 255-263. DOI: 10.1080/00420980120102957

Lundquist, L. J. (1991) Rolling stones for the resurrection of policy as the focus of comparative housing research. Scandinavian Housing and Planning Research, 8(2), pp. 79-90. DOI: 10.1080/02815739108730262

Lux, M. \& Mikeszova, M. (2012) Property restitution and private rental housing in transition: The case of the Czech Republic. Housing Studies, 27(1), pp. 77-96. DOI: 10.1080/02673037.2012.629643

Lux, M. \& Sunega, P. (2010) Private rental housing in the Czech Republic: Growth and .. . ? Czech Sociological Review, 46(3), pp. 349-373. DOI: $10.1080 / 02673037.2012 .629643$

Malpass, P. (ed.) (1997) Ownership, control and accountability: The new governance of housing. Coventry, The Chartered Institute of Housing.

Malpass, P. \& Means, R. (eds.) (1993) Implementing housing policy. Buckingham, Open University Press.

Mandič, S. (2000) Trends in central eastern European rented sectors. Journal of Housing and the Built Environment, 15(3), pp. 217-231. DOI: 10.1023/A:1010109920039

Mandič, S. \& Filipovič Hrast, M. (2015) Alternative socialnemu stanovanju: pogledi prosilcev o različnih možnostih. Urbani izziv, 26(1), pp. 5-16. DOI: 10.5379/urbani-izziv-2015-26-01-001

Matznetter, W. (2002) Social housing policy in a conservative welfare state: Austria as an example. Urban Studies 39(2), pp. 265-282. DOI: $10.1080 / 00420980120102966$

Monk, S. \& Whitehead, C. (eds.) (2000) Restructuring housing systems. York, Publishing Services Ltd. York.

Nacionalni stanovanjski program (Npsta). Uradni list Republike Slovenije, no. 43/2000. Ljubljana.

Oxley, M. (2004) Economics, planning and housing. New York, Palgrave Macmillan.

Pareja Eastaway, M. \& Varo, I. S. M. (2002) The tenure imbalance in Spain: The need for social housing policy. Urban Studies 39(2), pp. 283295. DOI: $10.1080 / 00420980120102975$

Pearl, M. (1997) Social housing management. A critical appraisal of housing practice. London, Macmillan.

Priemus, H. \& Dieleman, F. (2002) Social housing policy in the European Union: Past, present and perspectives. Urban Studies 39(2), pp. 191-200. DOI: 10.1080/00420980120102911

Priemus, H. \& Mandič, S. (2000) Rental housing in central and eastern Europe as no man's land. Journal of Housing and the Built Environment, 15(3), pp. 205-215. DOI: 10.1023/A:1010186618204

Ridley, N. (1988) The local right: Enabling not providing. London, Centre for Policy Studies. 
Rossi, P. H. \& Weber, E. (1996) The social benefits of home ownership: Empirical evidence from national surveys. Housing Policy Debate, 7(1), pp. 1-35. DOI: 10.1080/10511482.1996.9521212

Ruonavaara, H. (1990) Four models of explaining the growth of homeownership. Scandinavian Housing \& Planning Research, 7, pp. 129-142. DOI: $10.1080 / 02815739008730228$

Scanlon, K. \& Kochan, B. (2011) Towards a sustainable private rented sector. The lessons from other countries. London, The London School of Economics and Political Sciences.

Sendi, R. (1995) Housing reform and housing conflict: The privatisation and denationalisation of public housing in the Republic of Slovenia in practice. International Journal of Urban and Regional Research, 19(3), pp. 435-446. DOI: 10.1111/j.1468-2427.1995.tb00519.x

Sendi, R. (1999) Private rented housing in Slovenia: A non-existent housing sector? Netherlands Journal of Housing and the Built Environment, 14(3), pp. 309-322. DOI: 10.1007/BF02496684

Sendi, R., Mandič, S., Filipovič, M. \& Cirman, A. (2007) Stanovanjska reforma: pričakovanja, potrebe, realizacija. Ljubljana, Urbani izziv - publikacije.

Stamso, M. N. (2008) Grants for first-time homeowners in Norway - Distributional effects under different market and political conditions. International Journal of Housing Policy, 8(4), pp. 379-397. DOI: $10.1080 / 14616710802449703$

Statistical Office of the Republic of Slovenia (2012) Census report: People, families, housing. Ljubljana.

Struyk, R. J. (ed.) (1996) Economic restructuring of the former Soviet Bloc. The case of housing. Washington, DC, The Urban Institute Press.

Telgarsky, J. P. \& Struyk, R. J. (1990) Toward a market-oriented housing sector in Eastern Europe. Developments in Bulgaria, Czechoslovakia, Hungary, Poland, Romania, and Yugoslavia. Urban Institute Report 90-10. Washington, DC, The Urban Institute Press.

Toussaint, J. (2011) Housing assets as a potential solution for financial hardship: Household's mental accounts of housing wealth in three European countries. Housing, Theory and Society, 28(4), pp. 320-341. DOI:10.1080/14036096.2011.554853

Tsenkova, S. (2009) Housing policy reforms in post-socialist Europe. Lost in transition. Heidelberg, Pysica-Verlag. DOI: 10.1007/978-3-7908-2115-4

Turner, B., Hegedüs, J. \& Tosics, I. (eds.) (1992) The reform of housing in eastern Europe and the Soviet Union. New York, Routledge.

Turner, B. \& Whitehead, C. M. E. (2002) Reducing housing subsidy: Swedish housing policy in an international context. Urban Studies 39(2), pp. 201-217. DOI: $10.1080 / 00420980120102920$

United Nations Centre for Human Settlements (1992) Global strategy for shelter to the year 2000. Nairobi. 